\title{
Intelligence and Its Relationship to Achievement
}

\author{
Fatih KAYA ${ }^{1}$, Joyce JUNTUNE ${ }^{2}$, Laura STOUGH ${ }^{3}$
}

\begin{abstract}
This comprehensive literature review examines the link between intelligence and achievement. It also provides a brief summary of selected psychometric theories of intelligence. In attempt to gather all relevant scholarly literature, several procedures were used. A search of the key terms in the ERIC, PsycINFO, and Google Scholar databases was performed. The literature evidences that verbal abilities have stronger correlation with academic achievement than nonverbal abilities. Furthermore, verbal abilities are related to readiness to learn while nonverbal abilities are related to potential to learn. If intelligence scores are used to predict any kind of future academic performance, both verbal (readiness) and nonverbal (potential) abilities should be evaluated. Besides, in order to identify gifted and talented students, assessment of verbal abilities should accompany with the assessment of nonverbal abilities so that they will be able to survive in advanced academic programs.

Keywords: Intelligence, achievement, intelligence achievement relationship, theories of intelligence, gifted identification, literature review, testing
\end{abstract}

\section{INTRODUCTION}

Intelligence and achievement are two different, but interrelated, constructs. They have been studied for over a century in an attempt to explain differences in educational and life outcomes. The purpose of this article is to provide a comprehensive literature review on intelligence and achievement, their assessment, and their relationship to each other. An enhanced understanding of the relationship between intelligence, both verbal and nonverbal, and achievement may contribute to improving the identification of gifted and talented children, particularly those from low SES populations.

\section{Search Procedures}

In attempt to gather all relevant scholarly literature on the relationship between intelligence and achievement, several procedures were used. A search of the key terms in the ERIC, PsycINFO, and Google Scholar databases was performed. Each obtained article was read and analyzed. In addition, the reference lists from these articles were examined to find additional articles and literature that did not appear in the original database searches.

\section{Conceptualization of Intelligence}

The conceptualization of intelligence has received attention for over a century. Although researchers have tried to develop a single definition of intelligence, there are currently numerous definitions and explanations of intelligence. This lack of consensus on the definition of intelligence also contributes to disagreements about how to assess intelligence. The definition and interpretation of intelligence varies according to the model of intelligence to which an investigator adheres. Psychologists' definitions of intelligence often reflect intellectual goals, aspirations, or doubts rather than providing a clear definition of intelligence (Anastasi, 1986). Sternberg (2003) lists definitions of intelligence made by different researchers including "the power of good responses from the point of view of truth or facts (E. L. Thorndike), the ability to carry on abstract thinking (L. M. Terman), the capacity to inhibit an instinctive adjustment, the capacity to redefine the inhibited instinctive adjustment in the light of imaginably experienced trial and error, and the capacity to realize the modified instinctive adjustment in overt behavior to the advantage of the individual as a social animal (L. L. Thurstone), the capacity to learn or to

\footnotetext{
${ }^{1}$ Assist. Prof. Dr. Gaziosmanpasa University, Faculty of Education, e-mail: fatih.kaya@gop.edu.tr

2 Assoc. Prof. Dr. Texas A\&M University, College of Education and Human Development, e-mail: jjuntune@tamu.edu

${ }^{3}$ Assoc. Prof. Dr. Texas A\&M University, College of Education and Human Development, e-mail: lstough@tamu.edu
} 
profit by experience (W. F. Dearborn), and the capacity to acquire capacity (H. Woodrow)" (p. 6). In short, differences in definitions of intelligence arise from different conceptualizations by researchers.

Although there is no agreement on a single definition of intelligence, a survey by Snyderman and Rothman (1987) evidenced that most experts do agree on three definitional elements. These are a) abstract thinking or reasoning, b) the capacity to acquire knowledge, and c) problem solving ability. Gottfredson (1997) proposed a mainstream definition of intelligence along with several other collective statements on intelligence. Her definition, signed by 52 scholars in the field, was as follows:

Intelligence is a very general mental capability that, among other things, involves the ability to reason, plan, solve problems, think abstractly, comprehend complex ideas, learn quickly and learn from experience. It is not merely book learning, a narrow academic skill, or test-taking smarts. Rather, it reflects a broader and deeper capability for comprehending our surroundings - "catching on," "making sense" of things, or "figuring out" what to do. (p. 13)

\section{Psychometric Theories of Intelligence}

McGrew and Flanagan (1998) noted three different research traditions in the structural analysis of intelligence. These are the psychometric or structural approach, the information processing approach, and the cognitive modifiability approach. The first approach is based on data reduction techniques such as factor analysis. The second approach uses computer analogies to conceptualize as information processed during problem solving tasks. The last approach relies on the adaptable and changeable nature of intelligence and focuses on the dynamic assessment procedures. According to Neisser et al. (1996), the psychometric approach is the oldest and most dominant tradition. Brief summaries of selected psychometric theories of intelligence follow.

Spearman (1904), in his pioneering studies, used the technique of factor analysis and proposed a unitary view of intelligence. According to Spearman, a general factor or " $g$ ", plus one or more specific factors can explain people's performances on intelligence tests. People who perform well on a cognitive test tend to perform well on other tests because of the dominant $g$ factor. Spearman then concluded that intelligence is a general cognitive ability that could be measured and numerically expressed (1904). Jensen (1980) summarized the literature and noted that $g$ is correlated with several life outcomes including scholastic performance, reaction time, job performance, occupational status, earned income, and creativity. Spearman's $g$ can be considered the basis of several additional theories. It is also widely used by many intelligence test batteries that measure general cognitive ability.

Spearman's one-factor theory of intelligence was followed by Thurstone's multiple factor theory of intelligence (Thurstone, 1938). Thurstone proposed seven primary mental abilities; verbal reasoning, reasoning, perceptual speed, numerical ability, word fluency, associate memory, and spatial visualization. Thurstone's multi-factor theory of intelligence was entirely different from Spearman's single factor theory and other models that reflected dichotomous abilities. According to Thurstone (1938), intelligence should not be regarded as a unitary trait; however, it could be explained through primary mental abilities. In contrast to $g$, primary mental abilities, each which is equally important, are used to assess intelligence because $g$ factor has a minor role in explaining intelligence (Sattler, 1988). Although Thurstone challenged Spearman's theory of $g$, he later cautiously accepted the existence of a general factor (Wasserman \& Tulsky, 2005).

Guilford's Structure of the Intellect theory proposed three broad dimensions of intelligence, which he named content, operations, and products. Content is the information itself and has five categories: visual, auditory, symbolic, sematic, and behavioral. Operations encompass thinking processes and skills and involve six different thinking processes: evaluation, convergent production, divergent production, memory retention, memory recording, and cognition. Products are considered to be the consequences of the operations on the content. There are six types of products: units, classes, relations, systems, transformations, and implications. The interactions amongst these three dimensions are defined by 180 $(5 \times 6 \times 6=180)$ specific factors. Although Guilford's original model was composed of 120 human abilities, the number of factors was later increased to 180 (Guilford, 1988). 
Gardner's Theory of Multiple Intelligences (Gardner, 1983) and Sternberg's Triarchic Theory of Intelligence (Sternberg, 1985) introduced different views on the conceptualization of intelligence. Gottfredson (2006) asserted that the Theory of Multiple Intelligence was attractive to many people as everyone can be intelligent in some way but argued that empirical support for the theory was poor. Gottfredson (2003) also criticized Sternberg's Triarchic Theory due to its unempirical nature. She asserted that practical intelligence was not a broad aspect of cognition, rather a specific set of skills or task specific knowledge used to cope with a specific environment. Furthermore, traditional $g$-based intelligence tests can predict educational and social outcomes, indicators of practical intelligence such as income, occupational prestige, and staying out of jail.

The next era of psychometric theories of intelligence focused on dichotomous cognitive abilities. In addition to the $g$, the first level of analysis, two specific abilities became the focus of the second level of factor loadings, verbal and performance abilities. For example, the Wechsler Intelligence Scale for Children-Revised (WISC-R) and the Wechsler Adult Intelligence Scale-Revised (WAIS-R) both incorporate measures of these two abilities.

Modern multiple intelligence theories represent a third stage of development. As in the earlier stages, $g$ is at the first level in third stage theories, but more major factors are added to the second level, while several minor factors are added to the third level. Tests representative of this third stage of multiple intelligence theories are the Stanford-Binet Intelligence Scale-Fourth Edition (SBFE), and the Wechsler Intelligence Scale for Children-Third Edition (WISC-III).

The Differential Ability Scales (DAS; Elliot, 1990) and the Cognitive Assessment System (CAS; Naglieri, \& Das, 1996) represent the most recent developments in intelligence testing. The DAS accepts the presence of the $g$ factor, but its main focus is at the subtest level and yields individually interpretable subtests scores. The CAS, on the other hand, does not include $g$ as a factor, but emphasizes dynamic and interacting cognitive processes.

\section{Cattell-Horn Fluid and Crystallized Intelligence}

Willis, Dumont, and Kaufman (2011) view Spearman and Thurstone as representing two extremes of a continuum: Spearman proposes a general intelligence factor while Thurstone proposes seven separate primary abilities. However, the final formulation of these models made them conceptually closer. Spearman's acceptance of specific factors in addition to $g$ and Thurstone's acceptance of the presence of a general factor in addition to his seven primary abilities not only made these theories more closely aligned, but provided a foundation for later researchers to propose hierarchical theories or theories of multiple intelligence.

The Cattell and Horn Fluid-Crystallized $(\mathrm{G} f-\mathrm{G} c)$ theory is probably the best known and most widely used hierarchical theory of intelligence. Horn and Cattell (1966) claimed that primary mental abilities are organized at a general level into two types of intelligence, fluid and crystallized. The Gf-Gc intelligence model is one of the most comprehensive and empirically validated theories of intelligence (Flanagan \& McGrew, 1997). Messick (1992) compared contemporary multidimensional models of intelligence and concluded that $\mathrm{G} f-\mathrm{G} c$ theory of intelligence provided a more comprehensive network of validity evidence than did other theories.

Fluid intelligence is defined as the use of purposeful and controlled mental operations to solve novel problems that cannot be solved automatically or as a function of memorization. Some representative fluid mental operations are problem solving, identifying relations, comprehending implications, concept formation, classification, drawing inferences, transforming information, and inductive and deductive reasoning (McGrew, 2009; McGrew \& Evans, 2004). According to Willis, Dumont, and Kaufman (2011), fluid intelligence refers to:

... inductive, deductive, and quantitative reasoning with materials and process that are new to the person doing the reasoning. Fluid abilities allow an individual to think and act quickly, solve novel problems, and encode short-term memories. The vast majority of fluid reasoning task on intelligence tests use nonverbal, relatively culture-free stimuli, but require and integration of verbal and nonverbal thinking. (p. 44). 
Conversely, Horn and Cattell (as cited in Willis, Dumont, and Kaufman, 2011) explained crystallized intelligence as:

...the application of acquired knowledge and learned skills to answering questions and solving problems presenting at least broadly familiar materials and process. It is reflected in tests of knowledge, general information, use of language (vocabulary), and wide variety of acquired skills. (p. 44).

Willis, Dumont, and Kaufman continued, "Most verbal subtests of intelligence scales are classified primarily as measuring crystalized intelligence" (p. 44). For example, Shipley-2 is an intelligence test with verbal and nonverbal subtests, which assess crystallized and fluid intelligence respectively (Kaya, Delen, \& Bulut, 2012). Crystallized intelligence represents acquired knowledge (Cattell, 1963; Horn, 1991) and measures that represent it are therefore similar to achievement measures (Cattell \& Horn, 1978). Crystallized intelligence is composed of learning from past experiences; therefore, as people get older and accumulate new knowledge, crystallized intelligence becomes stronger. For example, the skills of reading comprehension and vocabulary are examples of crystallized intelligence.

Fluid intelligence is related to the $g$ factor (Ackerman, Beier, \& Boyle, 2002; Blair, 2006). Jensen (1998) reviewed five studies and noted that all specified a perfect correlation between $g$ and $\mathrm{G} f$. As a result of this perfect correlation, when all second-order factors are residualized, Gf totally disappeared. The residualized $\mathrm{G} c$ remained as a reflection of verbal-numerical-educational factor. Fluid intelligence is also a causal factor in learning, especially in novel situations (Kvist \& Gustafsson, 2008; Watkins, Lei, \& Canivez, 2007). As proposed by Cattell's investment theory (Cattell, 1971), fluid intelligence supports the acquisition of skills and knowledge that are the essence of crystallized intelligence. Fluid intelligence therefore provides a foundation for crystallized intelligence although they are two different constructs.

$\mathrm{G} f-\mathrm{G} c$ theory of intelligence has evolved much since its first version. Although the first version of the theory included only two factors (fluid and crystallized), more factors have been added, and the theory currently includes additional factors including, quantitative reasoning $(\mathrm{G} q)$, short-term memory (Gsm), visual processing $(\mathrm{G} v)$, auditory processing $(\mathrm{G} a)$, long-term retrieval $(\mathrm{G} l r)$, processing speed $(\mathrm{G} s)$, reading/writing (Grw), and correct decision speed (CDS). Horn and Noll (1997) assert that all human abilities can be represented by the factors included in this theory.

\section{Carroll's Three-Stratum Hierarchy}

John B. Carroll reanalyzed all usable correlational studies of mental tests data with factor analytic techniques and subsequently proposed his Three-Stratum Theory of Intelligence (Willis, Dumont, and Kaufman, 2011). Carroll's three-stratum model has a strong empirical foundation; and is considered the best representation of the structure of intelligence by many researchers in the field (Gottfredson \& Saklofske, 2009; Esters, Ittenbach, \& Han, 1997; Sternberg, 1994). Carroll's theory has three hierarchic levels (strata); $g$ is at the first level (stratum III), eight broad abilities, representing fluid intelligence (Gf), crystallized intelligence $(\mathrm{Gc})$, general memory and learning $(\mathrm{G} y)$, broad visual perception $(\mathrm{G} v)$, broad auditory perception $(\mathrm{G} u)$, broad retrieval ability $(\mathrm{G} r)$, broad cognitive speediness (Gs), and decision/reaction time/speed ( $\mathrm{G} t$ ) are at the second level (stratum II), followed by 69 narrowly defined specific abilities at the third level (stratum I) (Carroll, 1993).

The first two levels of Carroll's three-stratum model are actually parallel to the theory of fluid and crystallized intelligence proposed by Cattell and Horn. The similarity between these two most widely accepted theories of intelligence resulted in the formation of CHC theory (which stands for Cattell-HornCarroll) with represented a synthesis of all three researchers' works (McGrew, 2005). Appendix depicts the similarities between two theories. As shown in the appendix, Carroll's factor analytic analysis placed Cattell-Horn's quantitative reasoning $(\mathrm{G} q)$ within fluid intelligence $(\mathrm{G} f)$ and reading/writing $(\mathrm{G} r w)$ within crystallized intelligence $(\mathrm{Gc})$.

Fluid and crystallized intelligence are thus dichotomous factors of the original Cattell-Horn theory. The expanded stratum II abilities of CHC theory are described by Willis, Dumont, and Kaufman (2011): 
$\mathrm{G} v$, or visual-spatial thinking, involves a range of visual processes, ranging from fairly simple visual perceptual tasks to higher level, visual, cognitive processess.

$\mathrm{G} a$, auditory processing, involves tasks such as recognizing similarities and differences between sounds; recognizing degraded spoken words, such as words with sounds omitted or seperated; and mentally manipulating sounds in spoken words.

Gs, proocessing speed, refers to measures of clerical speed and accuracy, especially when there is pressure to maintain focused attention and concentration.

$\mathrm{G} t$, decision/reaction time or speed, reflects the immediacy (quickness) with which an individual can react and make a decision (decision speed) to typically simple stimuli.

Gsm, short-term memory, refers to the ability to take in and hold information in immediate memory and then to use it within a few seconds.

$\mathrm{G} l r$, long-term memory, involves memory storage and retrieval over longer periods of time than Gsm. How much longer varies from task to task. Glr refers to the efficiency of what is stored, not what is stored.

Grw, reading and writing, is part of Gc in Carroll's formulation. The narrow, stratum I abilities within Grw may not be sufficiently detailed to satisfy educators specialing in literacy.

$\mathrm{G} q$, knowledge, is dinstict from the quantitaive reasoning that is a narrow ability within Gf. (p. 48-49)

\section{Assessment of Intelligence}

The assessment of intelligence has been a focus of research along with the conceptualization of intelligence for over a century. However, intelligence cannot be assessed without clarity about the definition of intelligence. Some investigators such as Spearman and Thurstone define intelligence as what intelligence tests measure (Sternberg, 2003). Therefore, there are almost as many measures of intelligence as there are definitions. In addition, intelligence tests and the phrase "IQ tests" have been used interchangeably- although they are not at all equivalent (Urbina, 2011).

Intelligence can be measured with intelligence tests, which are among the most reliable and valid of psychological tests and assessments (Gottfredson, 1997). Standardized measures of intelligence predict many important educational, occupational, economic, and social outcomes (Gottfredson, 1997; Brody, 1992). Although intelligence tests have been criticized throughout the literature, most of the criticisms are associated with the inappropriate use of these tests and misinterpretation of the results rather than the tests themselves (Papanastasiou, 1999; Gottfredson \& Saklofske, 2009).

Anastasi and Urbina (1997) stated that while all human beings are equally valuable, they differ from each other in many ways. Cognitive capability or intelligence is one of the differences among human beings. The first intelligence test, which is the Binet-Simon Scale, was invented to measure the differences in students' cognitive capability and identify those who needed educational assistance (Urbina, 2011). Therefore, intelligence tests have been indispensable tools for explaining individual cognitive differences since the construction of the first one.

Galton developed the first tests with objective techniques to measure intelligence. He never claimed that his tests directly measured intelligence as they were designed to focus on physical measures, rather than upon higher mental processes (Wasserman \& Tulsky, 2005; Macintosh, 2011). James McKean Cattell attempted to measure mental abilities in a systematic manner. He included tests of higher cognitive tasks, in addition to Galton's sensory and motor tests. Alfred Binet, acknowledged as the father of intelligence testing, addressed the limitations of Galton and Cattell's assessment measures and developed the first working measure of intelligence. He first used the term "intelligence." As opposed to the Galton and Cattell's measure of motor and sensory measures, Binet's measure is an assessment of complex mental abilities (Wasserman \& Tulsky, 2005).

In 1905, Binet and Simon developed the Binet-Simon Scale to identify Parisian students with cognitive disabilities. This first scale was revised several times and extended for older age groups. These 
tests included the measurement of language, learning and memory, judgment and problem solving, auditory processing, and visual processing. Henry Goddard later introduced the Binet-Simon Scale to America in 1910. In 1916, Lewis Terman adapted the scale while at Stanford University, and named it the Stanford-Binet Intelligence Scale (Wasserman \& Tulsky, 2005). Most of the contemporary intelligence tests are direct descendants, modifications of, or responses to these first measures of Binet and Simon (Petrill \& Wilkerson, 2000).

The need to measure the intelligence of Army recruits during World War I prompted the use of the Army Alpha and Beta Test. Arthur Otis, a graduate student of Terman adapted the Stanford-Binet tests from individual to group administration. Group administration of IQ tests fostered its widespread use in schools, colleges, industry, and the military (Wasserman \& Tulsky, 2005).

Gottfredson (1998) stated, "Intelligence as measured by IQ tests is the single most effective predictor known of individual performance at school and on the job" (p. 24). This statement is acknowledged by most psychological researchers; however, the U.S. public generally dismisses it as given the belief that all people "born equally able and that social inequality results only from the exercise of unjust privilege" (Gottfredson, 1998, p. 24).

Standardized intelligence tests, which measure $g$, are popular and pervasive in education primarily because of the following reasons: they provide quantification of cognitive abilities, are easy to administer, time efficient, highly reliable, and replicable. Apart from $g$-based intelligence tests there are other intelligence tests based on modern multi-dimensional theories. However, it is difficult to assess intelligence with most of these tests because of their lower subtests reliabilities (Baldwin, 2005). Educators often prefer to use intelligence tests that can be administered quickly and provide reliable quantitative data (Baldwin, 2005). Standardized $g$-based intelligence tests have been preferred by the educators for more than a century, due to the aforementioned advantages.

\section{Understanding Achievement}

Achievement can be defined in different ways. The characteristic and scope of the definition also varies across time and individuals. Lindquist (1957) defined achievement as the degree of ability to perform on predetermined facts and concepts both quantitatively and qualitatively. Note that Lindquist used the phrase "ability to perform." From an educational perspective, the ability to perform is conceptualized as the academic ability to achieve in academic domains, such as reading and mathematics (Mayer, 2011). Mayer distinguishes between fluid and crystallized intelligence and draws a close connection between crystallized intelligence and academic achievement. He defines academic intelligence as an ability to learn or acquire knowledge from experience while defining academic achievement as what is learned or knowledge gained through experience.

As achievement is a broad and multidimensional construct (Jackson, 1976), the definition or understanding of the construct may stress different dimensions. For example, Steinberger (1993) stated how school administrators understand the concept of achievement:

Achievement encompasses student ability and performance; it is multidimensional; it is intricately related to human growth and cognitive, emotional, social, and physical development; it reflects the whole child; it is not related to a single instance, but occurs across time and levels, through a student's life in public school and on into post secondary years and working life. (p. 2)

According to Koretz (1997), the concept of educational achievement is specifically used in social science to refer to the mastery of knowledge and skills. It can also be defined as performance on a specific test and skill. Educational systems have also been conceived of as having inputs and outputs. Hanushek (1989) explained that quantifiable student characteristics can be considered as school inputs while student achievement test scores can be regarded as a measure of school output.

\section{Assessment of Achievement}

Educators, policy makers, and educators have been increasingly interested in the assessment of student achievement. This is particularly true in the U.S. where, on January $8^{\text {th }} 2002$, the No Child Left 
Behind Act of 2001 was signed by the President. This legislation (NCLB), with its accountability requirements, was enacted to assist in creating systemic school change through the assessment of student achievement. The factors that determine the achievement level of students have also received attention by many researchers. An assessment of the quality of a student's work in order to assess his or her educational achievement can be either overall achievement or subject-specific achievement, such as reading or math achievement.

Curriculum standards are part of most educational systems and students are expected to acquire knowledge and experiences to attain those standards. Educational systems usually have an assessment process that is aligned with standards in order to test students' level of learning or achievement. As stated by Jensen (1998), there are individual differences in rate of learning. Some people, under the same conditions of learning, may learn faster than others. Moreover, some may not be able to learn the same things that are learnt by others. Typically, children who learn more than their peers from the same experiences are regarded as above average or high achievers. Similarly, the children who learn less than their peers from the same experiences are considered as below average or underachievers. The measurement of these individual differences and level of learning are crucial in providing students with appropriate educational interventions or accommodations.

A variety of methods have been used by researchers to assess educational achievement. Schoolbased assessments such as final grades, grade point average, and teacher evaluations can be used to evaluate achievement. Standardized achievement tests, on the other hand, measure specific types of academic performance (Petrill \& Wilkerson, 2000), and some researchers such as McCall, Evahn, and Kratzer (1992) argue that standardized achievement tests are almost identical to intelligence tests. Jensen (1980) claimed that scores obtained from standardized achievement tests are more reliable and more highly correlated with cognitive abilities than are grades as teachers' perceptions of students may be influenced by students' personal characteristics.

The first standardized test of intelligence by Binet and Simon was developed to assess students who were most likely to fail in regular classes. Although it was a test designed to measure intelligence, it was used to predict students' future academic performances. According to Mayer (2011), Binet spread the idea that intelligence was reflected in achievement as his test measured knowledge that students were expected to acquire as a result of educational experiences.

Since educational achievement, as an educational output, is a primary concern of educators, policy makers, and parents, researchers focus on the underlying factors of achievement, in particular, how educational outputs vary according to the characteristics of input. Questions have explored the factors that affect students' educational outcomes and the determinants that explain the differences between high achievers and low achievers.

\section{Intelligence-Achievement Relation}

Intelligence has been considered as the most important cognitive factor that explains variations in achievement scores. Numerous studies have examined the relationship between intelligence and achievement. Although methodologies, data collection techniques, and variables included have varied, most studies show that intelligence and achievement are highly correlated. As a result, the relationship between general intelligence and academic achievement is now well established (Jensen, 1998).

Examining individual differences in educational outcomes and predicting academic success has been the principal objective of developing cognitive ability tests (Spearman, 1904; Ackerman \& Heggestad 1997). In assessing the predictive validity of intelligence tests, educational achievement is the primary target (Deary, Strand, Smith, \& Fernandes, 2007). General cognitive ability is a strong predictor of academic achievement (Gustafsson \& Undheim, 1996; Neisser et al., 1996) and, due to its strong predicting power, IQ tests are pervasive in schools and workplace settings (Kuncel, Hazlett, \& Ones, 2004; Schmidt \& Hunter, 1998).

Standardized intelligence tests based on $g$ are considered to best predict life outcomes such as job performance, academic success, and training (Jensen, 1998; Snow \& Yalow, 1982; Rolfhus \& Ackerman, 1999). General intelligence factor, $g$, is a strong predictor of achievement measured standardized tests 
(Gottfredson, 2005) and $g$ represents various types of intelligent behavior well (Jensen, 1980; Neisser et al., 1996).

Naglieri and Bornstein (2003) found that the Kaufman Assessment Battery for Children (K$\mathrm{ABC}$ ) and the Cognitive Assessment System (CAS), both which use multidimensional cognitive processing approaches to intelligence, predict academic achievement as well as do ability tests based on the general intelligence model. These researchers claim that the intelligence-achievement relations in these two tests are similar or stronger than are the correlations found by $g$ based ability tests. However, their investigation has some limitations and the tests used in their study have criticized by several researchers (e.g. McGrew, Flanagan, Keith, \& Vandewood, 1997) for not representing a full measure of cognitive functioning.

Although there is a broad agreement that intelligence has a positive effect on educational outcomes, the magnitude of the correlation has had little consistency across studies, being reported as somewhere from moderate to strong (Fischer et al., 1996; Herrnstein \& Murray, 1994). Jencks et al. (1979) reviewed eight samples from six different studies and reported a correlation ranging from .40 to .63 between intelligence test scores and the amount of education obtained. A more recent survey by Macintosh (1998) calculated a correlation range of .4 and .7 between intelligence scores and school performance grades. According to Gustafsson and Undheim (1996), the correlation is typically around .5. Gottfredson (2005) found the median correlation between IQ and achievement in standardized tests to be around .6; however, this correlation is reported to increase to .8 when different measures of achievement are combined into a single achievement score (see Jensen, 1998, p. 323-324).

The correlation between intelligence and achievement increases as the samples included in studies become more representative of the general population (Sternberg, Grigorenko, \& Bundy, 2001). The predictive validity of intelligence for achievement has been well demonstrated across ethnicity and SES (Sattler, 1988). In addition, intellectual abilities are predictive of achievement in reading, mathematics, social sciences, and science for all students regardless of ethnicity (Lohman, 2005)

Deary et al. (2007) conducted a study with a national cohort of 11year-old students in United Kingdom. Five years later, when the students were 16 years of age, national exam scores were used to assess their educational attainment. They reported a large effect size with the correlation of .81 between $g$ and latent variable of educational achievement. This study demonstrated that $g$ can explain up to twothirds of the variance in achievement.

Intelligence is also related to rate of learning. Several researchers demonstrated the relationship between IQ scores and academic progress with evidence that students with higher IQ scores show significantly greater academic progress in reading and writing than those with lower IQ scores (Shaywitz, Fletcher, Holahan, \& Shaywitz, 1992; Wise, Ring, \& Olson, 1999).

Ceci's (1991) review of the education literature on general intelligence attributes the relationship between IQ and achievement to the circumstances encountered in the learning environment. Ceci (1994) claims that measurement of general cognitive ability means simply educational achievement or acquired knowledge and argues that IQ scores are nothing more than school-related achievement scores. He also considers intellectual abilities, including $g$, as partially a product of scholastic performance (Ceci, 1992). Jensen (1998) counter argued that the strong correlation between intellectual abilities and scholastic performance did not mean that one predicts the other as there were other factors to consider for the unexplained variance. He stated that the two were strongly correlated but distinct constructs, and therefore it was inappropriate to assume that intelligence and achievement were equivalent. Jensen (1998) continued that intelligence, specifically $g$, proceeds achievement in the causal chain as $g$ is more pervasive in cognitive tasks than is achievement.

Causal effect of IQ on future academic achievement was investigated in a cross-lagged panel study by Watkins, Lei, and Canivez (2007). They tested 289 students with a test-retest interval of 2.8 years and reported that psychometric IQ had a causal effect on future achievement measures while achievement did not significantly affect future IQ scores. These results thus support Jensen's claim.

Intelligence is an important predictor not only for educational outcomes but also is associated with various social outcomes such as unemployment, incarceration, and illegitimate births. Scientific research 
on intelligence has shown evidence that people with higher IQ scores get better education, have more prestigious jobs, and earn higher income than do people with lower IQ scores (Gottfredson, 1997, 2003; Jensen, 1980, 1998; Schmidt \& Hunter, 2004). However, this body of research does not claim that differences in intelligence are the only predictor of such social outcomes (Gottfredson, 1997). Gagne and St. Pere (2002) noted that social science research rarely include intelligence as a research variable and point out that the causal function of intelligence could contribute to the understanding of many psychoeducational and psychosocial constructs if included as a variable in studies.

Beyond general cognitive ability, investigation of the specific relationships between specific cognitive abilities and academic achievement provides substantial contribution to the understanding of general ability and prevalent implications for practice and theory. In the literature, there are specific cognitive abilities - such as working memory, processing speed, and spatial ability - that have been shown to have an effect on academic achievement (Conway, Conwan, Bunting, Therriault, \& Minkoff, 2002; Fry \& Hale, 1996; Jensen \& Munro, 1979; Lubinski, Webb, Morelock, \& Benbow, 2001; Luo \& Petrill, 1999). Fry and Hale (1996) noted the significance of the combination of processing speed and working memory to explain individual differences in intellectual ability. According to Vernon (1983), some researchers consider processing speed as a bridge between working memory and general ability. Thus, he suggested that processing speed is crucial to represent individual differences in working memory and general ability. Luo, Thompson, and Detterman (2003) argued that mental speed is a strong mediator between general intelligence and academic achievement and found a shared variance of $30 \%$ between general intelligence and academic achievement was reduced to $6 \%$ when mental speed was controlled for. Rohde and Thompson (2007) examined the variation in academic achievement with general cognitive ability and specific cognitive abilities, such as working memory, spatial ability, and processing speed. They replicated the findings of Luo et al. (2003) and Lubinski et al.'s (2001) research with gifted students. However, added spatial ability as a specific cognitive ability, and found it predicted academic achievement. Spatial ability has also been found to be an important component of general ability as it contributes to the predictive validity of students' verbal and math scores (Shea, Lubinski, \& Benbow, 2001). Working memory, spatial ability, and processing speed are the specific cognitive abilities that are included in the CHC theory. Thus, many recent tests of cognitive abilities (i.e. Woodcock Johnson III and RIAS) that are based on the CHC theory include items to assess these specific cognitive abilities.

There has been expanding research that focuses on the relationships between different aspects of achievement and the various cognitive factors proposed by Horn-Cattell's Gf-Gc theory, Carroll's ThreeStratum theory, and the integration of both theories-the CHC theory. Flanagan and McGrew (1997) examined the predictive validity of $\mathrm{G} f-\mathrm{G} c$ specific cognitive abilities for academic achievement. Floyd, Evans, and McGrew (2003) found that CHC cognitive factors, when measured with cognitive clusters of the Woodcock Johnson III (WJ III) Test of Cognitive Abilities, were significantly related to mathematics achievement in a large, nationally representative sample of children and adolescents. They also found that crystalized intelligence had moderate relations with math calculation skills, and moderate to strong relationships with math reasoning. Fluid intelligence (Gf), short-term memory (Gsm), and working memory had moderate relationships with the mathematics clusters. In a related study, McGrew, Flanagan, Keith, and Vanderwood (1997) controlled the effects of $g$ by using structural equation modeling and found that $\mathrm{G} f, \mathrm{G} c$, and $\mathrm{G} s$ were strong predictors of math reasoning. Keith (1999) also evidenced that $g$ and other CHC broad cognitive abilities such as $\mathrm{G} c$, G $f$, Gs had influence on mathematics achievement. Similarly, Evans, Floyd, McGrew, and Leforgee (2002) found that structural equation modeling analysis of data from the Woodcock Johnson Pyschoeducational Battery-Revised (WJ-R) evidenced strong correlations between CHC cognitive factors and various aspects of reading achievement. Specifically, McGrew et al. (1997) and Keith (1997) reported significant correlations between auditory processing ( $\mathrm{G} a$ ) and crystalized intelligence $(\mathrm{Gc})$ and reading achievement in school-age children from the WJ-R standardization sample. Similarly, Garcia and Stafford (2000) conducted a regression analysis and revealed that reading achievement could be significantly predicted by $\mathrm{G} a$ and $\mathrm{G} c$ for first and second grade students from lower-income families. 
In addition to general cognitive ability's relationship with academic achievement, the role of verbal abilities on prediction of achievement scores should be noted. Verbal abilities are categorized in $\mathrm{CHC}$ and similar theories as crystallized intelligence. Research repeatedly shows that verbal abilities, as measured through cognitive tests, are one of the best predictors of academic achievement and schoolrelated performance (Flanagan, Andrews, \& Genshaft, 1997). In addition, verbal ability tests and verbal subtests of achievements tests have been demonstrated to be strongly correlated with general intelligence factor (Lee, Olszewski-Kubilius, \& Peternel, 2010).

Fisher (1995) found a positive correlation between IQ scores of elementary level students using the Otis-Lennon School Ability Test and final grades in the six subject areas of reading, English, social studies, science, and math. Jensen (1998) reported that the correlation between the academic achievement scores and IQ scores of high school students ranges from .50 to .70. Jensen (1980, p. 319) suggested that the magnitude of the correlation between IQ and achievement are highest in primary school and lower in middle school and college. However, this decrease can be generally explained by the restriction of range as a consequence of fewer students being enrolled in the upper grades.

\section{Verbal and Nonverbal Scores for Gifted Identification}

According to many intelligence theorists (e.g. Horn and Cattell, 1966), verbal and nonverbal cognitive abilities are the two main components of general intelligence. Hence, most of the standardized measures of intelligence include the assessment of verbal and nonverbal abilities. A well-validated measure of intelligence relies on a full measure of the construct, otherwise there will be construct underrepresentation (Warne, 2009), which, accordingly, represents a threat to test score validity (Braden, 2000).

Many school districts are faced with the challenge of increasing the diversity in gifted and talented education programs. In an attempt to solve this problem, they have recently moved to the use of nonverbal ability tests to identify and placed underrepresented minority students into gifted and talented programs (Lewis, DeCamp-Fritson, Ramage, McFarland, \& Archwamety, 2007; Lakin \& Lohman, 2011; Sacuzzo, Johnson, \& Russell, 1992). According to Lohman (2005), nonverbal tests generally include items that present visual stimuli and require nonverbal response, but the directions and feedback for the practice items are given orally. Lohman noted that items in nonverbal tests either need verbal or mathematical knowledge or the use of verbal or mathematical cognitive processes to solve presented tasks. As a result, it can be argued that there is not a test that is completely nonverbal (Lohman, 2005; Delen, Kaya, \& Ritter, 2012). Oller, Kim, and Choe (2000) list three kinds of evidence showing that nonverbal tests have been overrated: (a) pantomimed instructions cannot be understood by every test taker, (also noted by Lohman, 2005), (b) when there are complexities beyond the level of simple mazes, gestures do not make the instructions to nonverbal tasks understandable (Oller \& Chavez, 1997), and (c) theoretical arguments assert that complex nonverbal tasks require abstract verbal concepts as their basis. Such evidence points out a need for additional research on the relationship between verbal and nonverbal IQ scores.

Nonverbal tests also measure different functions than do verbal tests (Scarr, 1994). Factor analytic studies on the structure of human cognitive abilities routinely find that nonverbal intelligence tests can measure fluid intelligence well (Gustafsson \& Undheim, 1996), however do not measure intelligence well. This is problematic as Horn (1988) states, crystallized intelligence "may be what most people mean when they use the term intelligence" (p. 660).

Relying exclusively on nonverbal tests to identify gifted and talented students may also select some students who are less likely to achieve in advanced coursework: Strength in nonverbal intelligence is not the same as a combination of verbal and nonverbal intelligence (Lohman, 2005). Further, course requirements and achievement in advanced level programs require verbal abilities. Therefore, the students placed through the use of nonverbal tests, irregardless of their verbal scores, may not demonstrate subsequent high levels of achievement, as their verbal abilities may be less developed than are their nonverbal abilities. In any report or decision process, breaking down students' intelligence scores into verbal and nonverbal is crucial (Stanley, 1997). 


\section{Discussion}

Though there are numerous definitions for intelligence, most researchers agree that intelligence includes the following three elements: 1) abstract thinking, 2) the capacity to acquire knowledge, and 3) the ability to use that knowledge to problem solve. Intelligence is more than a storehouse of knowledge. Rather, intelligence includes the capability to use knowledge to make sense of the world around us.

Most theories of intelligence center around the concept of the existence of a general factor known as " $g$ " (Spearman, 1904). This " $g$ " can be measured and is correlated to things such as level of education, occupation, and economic status (Gottfredson, 1998). With the push in schools for all students to be college-ready by the time they graduate from high school, measurements of " $g$ " could explain why being college ready is more difficult for some students than others.

A strong relationship exists between general intelligence and academic achievement (Gottfredson, 2005, Jensen, 1998). This makes sense when we consider that intelligence is not only related to rate of learning, but to the understanding of complexities (Gottfredson, 1997). Classroom teachers are taught strategies for building achievement, but not how to use intelligence measures to effectively design instruction in a way that leads to increased achievement. The higher the level of intelligence, the easier it is to understand abstract content and comprehend the complexities of a mentally demanding career. However, a determined level of intelligence does not dictate that an individual cannot learn specific content or pursue a particular career. What it does tell us is how hard one might have to work to learn specific content or which careers will take more energy and effort if one is to pursue them with a high level of competency.

Understanding intelligence and its relationship to achievement is also crucial for educators charged with identifying and providing services to gifted students. Though it is common to use both an intelligence test and an achievement test in the identification process, when school districts are faced with large numbers of students from low socio-economic (SES) communities, they often resort to using a nonverbal intelligence test instead of a complete intelligence battery (Lewis, DeCamp-Fritson, Ramage, McFarland, \& Archwamety, 2007). These districts soon discover many low SES children are not able to keep pace with other gifted students and often leave the gifted program within a few years (Moore, Ford, \& Milner, 2005).

Is it that these students are not gifted, or is it that we are not providing them with the services they need to succeed? If educators do not understand the relationship between verbal intelligence and achievement, students with high nonverbal scores and low verbal scores will never be adequately served in existing gifted programs. In a 2 year study of 572 low-SES students, Juntune, Kaya, and Ramos (2011) found large point differences between verbal and nonverbal scores. First graders showed a 23.28-point difference, second graders a 22.05-point difference, and third graders a 20.23-point difference.

Warne (2009) reminds educators that gifted programs require verbal abilities. Therefore, an understanding of intelligence and its relationship to achievement can provide schools with diagnostic data which can be used to design services for gifted students from poverty which emphasize the development of verbal abilities for students with high nonverbal scores to better prepare these students to succeed academically.

\section{Conclusion}

The research performed thus far on intelligence and achievement has provided a firm foundation for understanding the relationship between these two constructs (Jensen, 1998). Primary cognitive abilities are organized into two main types of intelligence: fluid (nonverbal) and crystallized (verbal) (Horn \& Cattell, 1966). Verbal and nonverbal abilities can be assessed by many contemporary intelligence tests. The literature also evidences that verbal abilities have stronger correlation with academic achievement than nonverbal abilities. Furthermore, verbal abilities are related to readiness to learn while nonverbal abilities are related to potential to learn. If intelligence scores are used to predict any kind of future academic performance, both verbal (readiness) and nonverbal (potential) abilities should be evaluated.

Assessment of intelligence is one of the essential criteria for the identification of gifted and talented students. Any identification procedures based solely on nonverbal test scores may identify some 
students who have lower verbal scores or are not ready to learn. Consequently, these students may not be successful in gifted and talented education program and even may drop out of the program. Therefore, in order to identify students with high achievement and abilities and predict students' academic performance accurately, assessment of verbal abilities should accompany with the assessment of nonverbal abilities.

\section{References}

Ackerman, P. L., \& Heggestad, E. D. (1997). Intelligence, personality and interests: Evidence for overlapping traits. Psychological Bulletin, 121, 219-245. doi:10.1037//0033-2909.121.2.219

Ackerman, P. L., Beier, M. E., \& Boyle, M. O. (2002). Individual differences in working memory within a nomological network of cognitive and perceptual speed abilities. Journal of Experimental Psychology: General, 131, 567-589. doi: 10.1037//0096-3445.131.4.567

Anastasi, A. (1986). Intelligence as a quality of behavior. In R. J. Sternberg \& D. K. Detterman (Eds.), What is Intelligence? Contemporary viewpoints on its nature and definitions (pp. 19-21). Norwood, NJ: Ablex.

Anastasi, A., \& Urbina, S. (1997). Psychological testing. (7th ed.), Upper Saddle River, NJ: Prentice Hall.

Baldwin, A. Y. (2005). Identification concerns and promises for gifted students of diverse populations. Theory into Practice, 44, 105-114. doi:10.1207/s15430421tip4402_5

Blair, C. (2006). How similar are fluid cognition and general intelligence? A developmental neuroscience perspective on fluid cognition as an aspect of human cognitive ability. Behavioral and Brain Sciences, 29, 109-160. doi:10.1017/S0140525X06009034

Braden, J. P. (2000). Perspectives on the nonverbal assessment of intelligence. Journal of Psychoeducational Assessment, 18, 204-210. doi:10.1177/073428290001800301

Brody, N. (1992). Intelligence (2nd ed.). New York, NY: Academic Press.

Carroll, J. B. (1993). Human cognitive abilities: A survey of factor-analytic studies. New York, NY: Cambridge University Press.

Cattell, R. B. (1963). The theory of fluid and crystallized intelligence: A critical experiment. Journal of Educational Psychology, 54(1), 1-22. doi:10.1037/h0046743

Cattell, R. B. (1971). Abilities: Their structure, growth, and action. Boston, MA: Houghton-Mifflin.

Cattell, R. B., \& Horn, J. L. (1978). A check on the theory of fluid and crystallized intelligence with description of new subtest designs. Journal of Educational Measurement, 15, 139-164. doi:10.1111/j.17453984.1978.tb00065.x

Ceci, S. J. (1991). How much does schooling influence general intelligence and its cognitive components? A reassessment of the evidence. Developmental Psychology, 27(5), 703-722. doi:10.1037//00121649.27.5.703

Ceci, S. J. (1992). Schooling and intelligence. Psychological Science Agenda, 5, 7-9.

Ceci, S. J. (1994). Education, achievement, and general intelligence: What ever happened to the psycho in psychometrics? Psychological Inquiry, 5(3), 197-201. doi:10.1207/s15327965pli0503_4

Conway, A. R. A., Conwan, N., Bunting, M. F., Therriault, D. J., \& Minkoff, S. R. B. (2002). A latent variable analysis of working memory capacity, short-term memory capacity, processing speed, and general fluid intelligence. Intelligence, 30, 163-183. doi:10.1016/S0160-2896(01)00096-4

Deary, I. J., Strand, S., Smith, P., \& Fernandes, C. (2007). Intelligence and educational achievement. Intelligence, 35(1), 13-21. doi:10.1016/j.intell.2006.02.001

Delen, E., Kaya, F., \& Ritter N. (2012). Test review: Comprehensive test of nonverbal intelligence (CTONI2). Journal of Psychoeducational Assessment, 30(2), 209-213. doi:10.1177/0734282911415614

Elliot, C. D. (1990). Differential Ability Scales. San Antonio, TX: Psychological Corporation.

Esters, I. G., Ittenbach, R. F., \& Han, K. (1997). Today's IQ tests: Are they really better than their historical predecessors? School Psychology Review, 26(2), 211-224.

Evans, J. J., Floyd, R. G., McGrew, K. S., \& Leforgee, M. H. (2002). The relations between measures of Cattell-Horn-Carroll (CHC) cognitive abilities and reading achievement during childhood and adolescence. School Psychology Review, 31(2), 246-262.

Fischer, C. S., Hout, M., Jankowski, M. S., Lucas, S. R., Swidler, A., \& Voss, K. (1996). Inequality by design: Cracking the bell curve myth. Princeton, NJ: Princeton University Press.

Fisher, J. L. (1995). Relationship of intelligence quotients to academic achievement in the elementary grades. Retrieved September 2, 2011, from http://lib- 
ezproxy.tamu.edu:2048/login?url=http://search.ebscohost.com/login.aspx?direct=true\&db=eric\&AN= ED388428\& site $=$ ehost-live

Flanagan, D. P., \& McGrew, K. S. (1997). A cross-battery approach to assessing and interpreting cognitive abilities: Narrowing the gap between practice and cognitive science. In D. P. Flanagan, J. L. Genshaft, \& P. L. Harrison (Eds.), Contemporary intellectual assessment: Theories, tests, and issues (pp. 314325). New York, NY: Guilford.

Flanagan, D. P., Andrews, T. J., \& Genshaft, J. L. (1997). The functional utility of intelligence tests with special education populations. In D. P. Flanagan, J. L. Genshaft, \& P. L. Harrison (Eds.), Contemporary intellectual assessment: Theories, tests, and issues (pp. 457-483). New York, NY: Guilford.

Flanagan, D. P., Ortiz, S. O., Alfonso, V. C., \& Mascolo, J. T. (2002). The Achievement Test Desk Reference (ADTR): Comprehensive assessment and learning disabilities. Boston, MA: Allyn \& Bacon.

Floyd, R. G., Evans, J. J., \& McGrew, K. S. (2003). Relations between measures of Cattell-Horn-Carroll (CHC) cognitive abilities and mathematics achievement across the school-age years. Psychology in the Schools, 40(2), 155-171. doi:10.1002/pits.10083

Fry, A. F., \& Hale, S. (1996). Processing speed, working memory, and fluid intelligence: Evidence for a developmental cascade. Psychological Science, 7(4), 237-241. doi:10.1111/j.14679280.1996.tb00366.x

Gagne, F., \& St. Pere, F. (2002). When IQ is controlled, does motivation still predict achievement? Intelligence, 30(1), 71-100.

Garcia, G. M., \& Stafford, M. E. (2000). Prediction of reading by $G a$ and $G c$ specific cognitive abilities for low-SES White and Hispanic English-speaking children. Psychology in the Schools, 37, 227-235. doi:10.1002/(SICI)1520-6807(200005)37:3<227::AID-PITS3>3.0.CO;2-T

Gardner, H. (1983) Frames of Mind: The Theory of Multiple Intelligences. New York, NY: Basic Books.

Gottfredson, L. (2003). Dissecting practical intelligence theory: Its claims and its evidence. Intelligence, 31, 343-397.

Gottfredson, L. S. (1997). Mainstream science on intelligence: An editorial with 52 signatories, history, and bibliography. Intelligence, 24(1), 13-23. doi:10.1016/S0160-2896(97)90011-8

Gottfredson, L. S. (1998, Winter). The general intelligence factor. Scientific American Presents, 9(4), 24-29.

Gottfredson, L. S. (2005). Implications of cognitive differences for schooling within diverse societies. In C. L. Frisby \& C. R. Reynolds (Eds.), Comprehensive handbook of multicultural school psychology. (pp. 517-554). New York, NY: Wiley.

Gottfredson, L. S. (2006). Social consequences of group differences in cognitive ability (Consequencias sociais das diferencas de grupo em habilidade cognitiva). In C. E. Flores-Mendoza \& R. Colom (Eds.), Introducau a psicologia das diferencas individuais (pp. 433-456). Porto Allegre, Brazil: ArtMed Publishers.

Gottfredson, L., \& Saklofske, D. H. (2009). Intelligence: Foundations and issues in assessment. Canadian Psychology, 50(3), 183-195. doi:10.1037/a0016641

Guilford, J. P. (1988). Some changes in the structure of intellect model. Educational and Psychological Measurement 48, 1-4. doi:10.1177/001316448804800102

Gustafsson, J. E., \& Undheim, J. O. (1996). Individual differences in cognitive functions. In D. C. Berliner \& R. C. Calfee (Eds.), Handbook of educational psychology (pp. 186-242). New York, NY: Simon \& Schuster Macmillan.

Hanushek, E. A. (1989). The impact of differential expenditures on school performance. Educational Researcher, 18(4), 45-51. doi:10.2307/1176650

Herrnstein, R. J., \& Murray, C. (1994). The bell curve: Intelligence and class structure in American life. New York, NY: Free Press.

Horn, J. L. (1988). Thinking about human abilities. In J. R. Nesselroade \& R. B. Cattell (Eds.), Handbook of multivariate experimental psychology (2nd ed., pp. 645-685). New York, NY: Plenum. doi:10.1007/978-1-4613-0893-5_19

Horn, J. L. (1991). Measurement of intellectual capabilities: A review of theory. In K. S. McGrew, J. K. Werder, \& R. W. Woodcock (Eds.), WJ-R technical manual (pp. 197-232). Chicago, IL: Riverside. 
Horn, J. L., \& Cattell, R. B. (1966). Refinement and test of the theory of fluid and crystallized general intelligence. Journal of Educational Psychology, 57, 253-270. doi:10.1037/h0023816

Horn, J. L., \& Noll, J. (1997). Human cognitive capabilities: Gf-Gc theory. In D. P. Flanagan, J. L. Genshaft, \& P. L. Harrison (Eds.), Contemporary intellectual assessment: Theories, tests and issues (pp. 53-91). New York, NY: Guilford.

Jackson, D. N. (1976). Is achievement a unitary construct? Journal of Research in Personality, 10(1), 1-21. doi:10.1016/0092-6566(76)90079-9

Jencks, C., Bartlett, S., Corcoran, M., Crouse, J., Eaglesfield, D., Jackson, G., ... Williams, J. (1979). Who gets ahead? The determinants of economic success in America. New York, NY: Basic Books.

Jensen, A. R. (1980). Bias in mental testing. New York, NY: Free Press.

Jensen, A. R. (1998). The g factor: The science of mental ability. Westport, CT: Praeger.

Jensen, A. R., \& Munro, E. (1979). Reaction time, movement time, and intelligence. Intelligence, 3, 121-126. doi:10.1016/0160-2896(79)90010-2

Juntune, J., Kaya, F., \& Ramos, S. (2011). Another look at high ability students from low SES populations. Teтpo, 32(4), 14-19.

Kaya, F., Delen, E., \& Bulut, O. (2012). Test review: Shipley-2. Journal of Psychoeducational Assessment, 30, 593-597. doi:10.1177/0734282912440852

Keith, T. Z. (1997). Using confirmatory factor analysis to aid in understanding the constructs measured by intelligence tests. In D. P. Flanagan, J. L. Genshaft, \& P. L. Harrison (Eds.), Contemporary intellectual assessment: Theories, tests, and issues (pp. 373-402). New York, NY: Guilford.

Keith, T. Z. (1999). Effects of general and specific abilities on student achievement: Similarities and differences across ethnic groups. School Psychology Quarterly, 14, 239-262. doi:10.1037/h0089008

Koretz, D. (1997). Indicators of educational achievement. In R. M. Hauser, B. V. Brown, \& W. R. Prosser (Eds.), Indicators of children's well-being (pp. 208-234). New York, NY: Russell Sage Foundation.

Kuncel, N. R., Hezlett, S. A., \& Ones, D. S. (2004). Academic performance, career potential, creativity, and job performance: Can one construct predict them all? Journal of Personality \& Social Psychology, 86(1), 148-161. doi:10.1037/0022-3514.86.1.148

Kvist, A. V., \& Gustafsson, J. (2008). The relation between fluid intelligence and the general factor as a function of cultural background: A test of Cattell's investment theory. Intelligence, 36, 422-436.

Lakin, J. M., \& Lohman, D. F. (2011). The predictive accuracy of verbal, quantitative, and nonverbal reasoning tests: Consequences for talent identification and program diversity. Journal for the Education of the Gifted, 34(4), 595-623. doi:10.1177/016235321103400404

Lee, S., Olszewski-Kubilius, P., \& Peternel, G. (2010). Achievement after participation in a preparatory program for verbally talented students. Roeper Review, 32(3), 150-163. doi: 10.1080/02783193.2010.485301

Lewis, J. D., DeCamp-Fritson, S. S., Ramage, J. C., McFarland, M. A., \& Archwamety, T. (2007). Selecting for ethnically diverse children who may be gifted using Raven's standard progressive matrices and Naglieri nonverbal abilities test. Multicultural Education, 15(1), 38-42.

Lindquits, E. F. (1957). The Iowa Test of Educational Development: Confidential Summary report of Average Scores. Chacago, IL: Science Research Associates.

Lohman, D. F. (2005). The role of nonverbal ability tests in identifying academically gifted students: An aptitude perspective. Gifted Child Quarterly, 49, 111-138. doi:10.1177/001698620504900203

Lubinski, D., Webb, R. M., Morelock, M. J., \& Benbow, C. P. (2001). Top 1 in 10,000: A 10-year follow-up of the profoundly gifted. Journal of Applied Psychology, 86(4), 718-729. doi:10.1037//00219010.86.4.718

Luo, D., \& Petrill, S. A. (1999). Elementary cognitive tasks and their role in g estimates. Intelligence, 27(2), 157-174. doi:10.1016/S0160-2896(99)00020-3

Luo, D., Thompson, L. A., \& Detterman, D. K. (2003). The casual factor underlying the correlation between psychometric $g$ and scholastic performance. Intelligence, 31(1), 67-83.

Mackintosh, N. J. (1998). IQ and human intelligence. Oxford: Oxford University Press.

Mackintosh, N. J. (2011). History of theories and measurement of intelligence. In R. J. Sternberg \& S. B. Kaufman (Eds.), The Cambridge handbook of intelligence (pp. 3-19). New York, NY: Cambridge University Press. 
Mayer, R. E. (2011). Intelligence and achievement. In R. J. Sternberg \& S. B. Kaufman (Eds.), The Cambridge handbook of intelligence (pp. 738-747). New York, NY: Cambridge University Press.

McCall, R. B., Evahn, C., \& Kratzer, L. (1992). High school underachievers: What do they achieve as adults? London, England: Sage.

McGrew, K. S. (2005). The Cattell-Horn-Carroll theory of cognitive abilities. In D. P. Flanagan \& P. L. Harrison (Eds.), Contemporary intellectual assessment: Theories, tests, and issues (2nd ed., pp. 136181). New York, NY: Guilford.

McGrew, K. S. (2009). CHC theory and the human cognitive abilities project: Standing on the shoulders of the giants of psychometric intelligence research. Intelligence, 37, 1-10. doi:10.1016/j.intell.2008.08.004

McGrew, K. S., \& Evans, J. J. (2004). Internal and external factorial extensions to the Cattell-Horn-Carroll (CHC) theory of cognitive abilities: A review of factor analytic research since Carroll's Seminal 1993 Treatises. St. Cloud, MN: Institute for Applied Psychometrics.

McGrew, K. S., \& Flanagan, D. P. (1998). The intelligence test desk reference (ITDR): Gf-Gc crossbattery assessment.Boston, MA: Allyn and Bacon.

McGrew, K. S., Flanagan, D. P., Keith, T. Z., \& Vanderwood, M. (1997). Beyond g. The impact of Gf-Gc specific cognitive abilities research on the future use and interpretation of intelligence tests in the schools. School Psychology Review, 26, 177-189.

Messick, S. (1992). Multiple intelligences or multilevel intelligence? Selective emphasis on distinctive properties of hierarchy: On Gardner's Frames of Mind and Sternberg's Beyond IQ in the context of theory and research on the structure of human abilities. Psychological Inquiry, 3, 365-384. doi:10.1207/s15327965pli0304_20

Moore, J. L., III, Ford, D. Y., \& Milner, H. R. (2005). Recruitment is not enough: Retaining African American students in gifted education, Gifted Child Quarterly, 49, 51-67. doi: 10.1177/001698620504900106

Naglieri, J. A., \& Bornstein, B. T. (2003). Intelligence and achievement: Just how correlated are they? Journal of Psychoeducational Assessment, 21, 244-260. doi:10.1177/073428290302100302

Naglieri, J. A., \& Das, J. P. (1996). Das Naglieri Cognitive Assessment System. Chicago, IL: Riverside.

Neisser, U., Boodoo, G., Bouchard, T. J., Jr., Boykin, A. W., Brody, N., Ceci, S., Urbina, S. (1996). Intelligence: knowns and unknowns. American Psychologist, 51(2), 77-101. doi:10.1037//0003066X.51.2.77

Oller, J. W., Jr., \& Chavez, M. (1997, August). A closer look at non-verbal IQ tests. Poster presented at the conference of the Cognitive Science Society, Stanford University, Palo Alto, CA.

Oller, J. W., Jr., Kim, K. \& Choe, Y. (2000). Testing verbal (language) and nonverbal abilities in language minorities: A socio-educational problem in historical perspective. Language Testing, 17(3), 341-360.

Papanastasiou, E. C. (1999). Intelligence: Theories and testing. Retrieved from http://www.eric.ed.gov/contentdelivery/servlet/ERICServlet?accno=ED441859

Petrill, S. A., \& Wilkerson, B. (2000). Intelligence and achievement: A behavioral genetic perspective. Educational Psychology Review, 12, 185-199.

Rohde, T. E, \& Thompson, L. A. (2007). Predicting academic achievement with cognitive ability. Intelligence, 35, 83-92. doi:10.1016/j.intell.2006.05.004

Rolfhus, E. L., \& Ackerman, P. L. (1999). Assessing individual differences in knowledge: Knowledge, intelligence, and related traits. Journal of Educational Psychology, 91, 511-526. doi:10.1037//00220663.91.3.511

Saccuzzo, D. P., Johnson, N. E., \& Russell, G. (1992). Verbal versus performance IQs for gifted AfricanAmerican, Caucasian, Filipino, and Hispanic children. Psychological Assessment, 4, 239-244. doi:10.1037//1040-3590.4.2.239

Sattler, J. M. (1988). Assessment of children (3rd ed.). San Diego, CA: Sattler.

Scarr, S. (1994). Culture-fair and culture-free tests. In R. J. Sternberg (Ed.), Encyclopedia of human intelligence (pp. 322-328). New York, NY: Macmillan.

Schmidt, F. L., \& Hunter, J. E. (1998). The validity and utility of selection methods in personnel psychology: Practical and theoretical implications of 85 years of research findings. Psychological Bulletin, 124, 262-274. doi:10.1037//0033-2909.124.2.262 
Schmidt, F. L., \& Hunter, J. E. (2004). General mental ability in the world of work: Occupational attainment and job performance. Journal of Personality and Social Psychology, 86, 162-173. doi:10.1037/00223514.86.1.162

Shaywitz, B. A., Fletcher, J. M., Holahan, J. M., \& Shaywitz, S. E. (1992). Discrepancy compared to low achievement definitions of reading disability: Results from the Connecticut longitudinal study. Journal of Learning Disabilities, 25, 639-648. doi:10.1177/002221949202501003

Shea, D. L., Lubinski, D., \& Benbow, C. P. (2001). Importance of assessing spatial ability in intellectually talented young adolescents: A 20-year longitudinal study. Journal of Educational Psychology, 93(3), 604-614. doi:10.1037/0022-0663.93.3.604

Snow, R. E., \& Yalow, E. (1982). Education and intelligence. In R. J. Sternberg (Ed.), Handbook of intelligence (pp. 493-585). Cambridge, England: University Press.

Snyderman, M. \& Rothman, S. (1987). Survey of expert opinion on intelligence and aptitude testing. American Psychologist, 42, 137-144. doi:10.1037//0003-066X.42.2.137

Spearman, C. (1904). "General intelligence," objectively determined and measured. American Journal of Psychology 15, 201-293. doi:10.2307/1412107

Stanley, J. C. (1997). Varieties of intellectual talent. Journal of Creative Behavior. 31(2), 93-119. doi:10.1002/j.2162-6057.1997.tb00783.x

Steinberger, E. D. (1993). Improving student achievement. Arlington, VA: American Association of School Administrators.

Sternberg, R. J. (1985). Beyond IQ: A triarchic theory of human intelligence. New York, NY: Cambridge University Press.

Sternberg, R. J. (1994). 468 factor-analyzed data sets: What they tell us and don't tell us about human intelligence. [Review of the book Human cognitive abilities, by John B. Carroll]. Psychological Science, 5(2), 63-65.

Sternberg, R. J. (2003). Wisdom, intelligence, and creativity synthesized. New York, NY: Cambridge University Press. doi:10.1017/CBO9780511509612

Sternberg, R. J., Grigorenko, E. L., \& Bundy, D. A. (2001). The predictive value of IQ. Merrill-Palmer Quarterly, 47, 1-41. doi:10.1353/mpq.2001.0005

Thurstone, L. L. (1938). Primary mental abilities. Chicago, IL: University of Chicago Press.

Urbina, S. (2011). Tests of intelligence. In R. J. Sternberg \& S. B. Kaufman (Eds.), The Cambridge handbook of intelligence (pp. 20-38). New York, NY: Cambridge University Press.

Vernon, P. A. (1983). Speed of information processing and general intelligence. Intelligence, 7, 53-70. doi:10.1016/0160-2896(83)90006-5

Warne, R. T. (2009). Comparing tests used to identify ethnically diverse gifted children: A critical response to Lewis, DeCamp-Fritson, Ramage, McFarland, \& Archwamety. Multicultural Education, 17(1), 48-53.

Wasserman, J. D., \& Tulsky, D. S. (2005). The origins of intellectual processing. In D. P. Flanagan \& P. L. Harrison (Eds.), Contemporary intellectual assessment: Theories, tests, and issues (2nd ed., pp. 3-38). New York, NY: Guilford.

Watkins, M. W., Lei, P., \& Canivez, G. L. (2007). Psychometric intelligence and achievement: A cross-lagged panel analysis. Intelligence, 35, 59-68. doi:10.1016/j.intell.2006.04.005

Willis, J. O., Dumont, R., \& Kaufman, A. S. (2011). Factor-Analytic Models of intelligence. In R. J. Sternberg \& S. B. Kaufman (Eds.), The Cambridge handbook of intelligence (pp. 39-57). New York, NY: Cambridge University Press.

Wise, B. W., Ring, J., \& Olson, R. K., (1999). Training phonological awareness with and without explicit attention to articulation. Journal of Experimental Child Psychology, 72, 271-304.

doi:10.1006/jecp.1999.2490 


\title{
Zekâ ve Akademik Başarı Arasındaki İlişsisi
}

\author{
Fatih KAYA ${ }^{1}$, Joyce JUNTUNE ${ }^{2}$, Laura STOUGH ${ }^{3}$
}

\begin{abstract}
ÖZ. Bu kapsamlı literatür taraması zeka ve akademik başarı arasındaki ilişkiyi incelemektedir. Ayrıca seçilmiş psikometrik zekâ kuramları hakkında da bir özet sunmaktadır. Bu taramada ilgili literatüre ulaşmak için çeşitli yöntemler kullanılmıştır. ERIC, PsycINFO ve Google Akademik'te belirlenmiş anahtar kelimelerle aramalar gerçekleştirilmiş̧ir. Elde edilen literatüre göre, sözel yeteneklerin akademik başarı ile olan ilişkisi sözel olmayan yeteneklerinkinden daha güçlüdür. Bunun ötesinde, sözel yetenekler öğrenmeye hazırbulunuşluk ile ilişkiliyken, sözel olmayan yetenekler öğrenme potansiyeli ile ilişkilidir. Zekâ puanları gelecekteki herhangi bir akademik performansı yordamak için kullanılacaksa, sözel ve sözel olmayan zekâ puanları birlikte değerlendirilmelidir. Ayrıca, üstün zekâlı ve yetenekli öğrencilerin tanılanmasında, sözel zekâ puanları sözel olmayan zekâ puanları ile birlikte kullanılmalıdır ki, bu öğrenciler yerleştirildikleri ileri seviye programlarda başarılı olabilsinler.

Anahtar kelimeler: Zeka, akademik başarı, zeka ve akademik başarı ilişkisi, zeka kuramları, üstün zekalıların tanılanması, literatür taraması, test
\end{abstract}

Amaç ve Önem: Zekâ ve başarı kavramları birbirinden ayrı ama birbiri ile ilişkili iki kavramdır. Zekâ ve akademik başarı kavramları üzerinde yapılan araştırmalar, akademik ve insan yaşamının diğer boyutlarındaki bireysel farklılıkları açıklamak için yüzyıldan fazla bir zamandır devam etmektedir. Bu çalışmanın amacı, zeka ve akademik başarı üzerine kapsamlı bir literatür taraması sunmaktır. Bu çalışma ayrıca bu iki kavramın nasıl ölçüldüğü ve birbiri ile olan ilişkisi hakkında da kapsamlı bilgi sağlamaktadır. Sözel ve sözel olmayan boyutları ile zekâ ve zekânın akademik başarı ile ilişkisinin anlaşılması, özellikle düşük sosyo-ekonomik düzeydeki ailelerden gelenler olmak üzere üstün zekâlı ve yetenekli öğrencilerin daha uygun şekilde tanılanmasına katkı sağlayacaktır.

Yöntem: Zekâ ve akademik başarı arasındaki ilişkiyi konu alan akademik literatüre ulaşmak için çeşitli yöntemler kullanılmıştır. Öncelikle literatürde arama yapılacak anahtar kelimeler belirlenmiş ve ERIC, PSychINFO ve Google Scholar veritabanlarında bu anahtar kelimelerle aramalar gerçekleştirilmiştir. Ulaşılan her bir makale okunmuş ve bu makalelerin kısa özetleri çıkarılmıştır. Daha sonra bu makalelerin kaynakça listelerinde yer alan ilgili makalelere de ulaşılarak ilk aramada ulaşılamayan makaleler de araştırmaya dâhil edilmiştir. Bütün makaleler okunduktan sonra konularına ve alt konularına göre tasnif edilmiş ve literatür yazımına geçilmiştir.

Bulgular: Zekânın tanımlanması ve yorumlanması araştırmacıların benimsedikleri modele veya yaklaşıma göre çeşitlilik göstermektedir. Araştırmacıların zekâ tanımları, net bir tanım üretmekten daha çok zekâ ile ilgili olarak kendi isteklerini, şüphelerini veya entelektüel hedeflerini yansıtmaktadır (Anastasi, 1986). Sternberg (2003) pek çok araştırmacı tarafından önerilen çeşitli tanımları kitabında bir araya getirmiş ve tanımlar arasındaki farklara ve ortak yanlara dikkat çekmiştir. Zekânın kavramsallaştırılmasının zor olması ve tek bir tanım üzerinde fikir birliği bulunmaması, zekânın nasıl ölçüleceği ve nasıl değerlendirileceği ile ilgili olarak da bir fikir birliğinin olmamasının en büyük nedenidir. Zekâ ile ilgili kuramlar yüzyılı aşan bir zaman diliminde Spearman (1904) ile başlayıp Thurstone (1938), Guilford (1988) ve Gardner (1983) ile devam etmiştir. Cattell ve Horn (1966) tarafından ortaya atılan akışkan ve kristalize zekâ kuramı ise belki de en çok bilinen ve en yaygın olarak kabul gören hiyerarşik zekâ kuramıdır (Flanagan ve McGrew, 1997). Zekâ ile ilgili her kuram veya modelin önerdiği kendi özelliklerine uygun farklı ölçme ve değerlendirme ölçütleri bulunmaktadır.

Akademik başarıdaki bireysel farklılıkları açıklamak için sıklıkla kullanılan bilişsel faktörlerin en başında geleni zekâdır. Zekâ ve akademik başarı arasındaki ilişki artık literatürde yaygın bir şekilde kabul görmektedir (Jensen, 1998). Bu ilişki Gustafsson ve Undheim (1996)'a göre 0,5 civarındadır. Gottfredson (2005)'a göre ise standart testlerden alınan zeka ve akademik başarı puanları arasındaki korelasyon ortalama 0,6 civarında olup

1 Yrd. Doç. Dr. Gaziosmanpaşa Üniversitesi, Eğitim Fakültesi, e-posta: fatih.kaya @ gop.edu.tr

2 Doç. Dr. Texas A\&M Üniversitesi, Eğitim Fakültesi, e-posta: j-juntune@ @amu.edu

${ }^{3}$ Doç. Dr. Texas A\&M Üniversitesi, Eğitim Fakültesi, e-posta: 1stough@tamu.edu 
0,8'e kadar çıkabilmektedir.

Cattell-Horn Zeka Kuramı (1966)'na göre, sözel ve sözel olmayan (akışkan ve kristalize) zeka türleri genel zekayı oluşturan iki büyük bileşendir. Bu kurama göre genel zekânın ölçülmesinde hem sözel hem de sözel olmayan yetenekler ölçülmelidir.

Tartışma, Sonuç ve Öneriler: Bilişsel yetenekler başlıca iki tür zekâ altında toplanmıştır: akışkan (sözel olmayan) ve kristalize (kristalize) (Horn ve Cattell, 1966). Sözel ve sözel olmayan yetenekler pek çok farklı zekâ testi ile ölçülebilir. Literatür sözel yeteneklerin sözel olmayan yeteneklere göre akademik başarı ile daha yüksek bir korelasyona sahip olduğunu göstermektedir. Buna ek olarak, sözel yetenekler öğrenme için hazırbulunuşluk ile ilgiliyken, sözel olmayan yetenekler daha çok öğrenme potansiyeli ile ilgilidir. Bundan dolayı, zekâ puanları öğrencilerin gelecekteki herhangi bir başarısını yordamak için kullanılacaksa, hem sözel hem de sözel olmayan yetenekler birlikte değerlendirilmelidir.

Zekânın ölçülmesi, üstün zekâlı ve yetenekli öğrencilerin tanılanmasında sıklıkla kullanılan en temel ölçütlerden birisidir. Sadece sözel olmayan yeteneklere ağırlık veren tanılama süreçleri, üstün zekâlı ve yetenekliler programları için sözel yetenek seviyeleri yeterli olmayan ve dolayısıyla öğrenme için hazır olmayan çocukları tanılayabilmektedir. Sonuç olarak, bu çocuklar üstün zekâlı ve yetenekliler programlarında başarılı olamayıp programdan çıkarılmak zorunda bile kalabilmektedirler. Bundan dolayı, üstün yetenekli ve yüksek başarı düzeyine sahip öğrencilerin tanılanması ve bu öğrencilerin gelecekteki akademik performanslarını doğru bir şekilde yordanması amaçlanıyorsa, sözel ve sözel olmayan yetenekler birlikte ölçülmeli ve değerlendirilmelidir. 
Appendix

A comparison of Cattell-Horn Gf-Gc and Carroll's three-startum theories. Adapted from Flanagan, Ortiz, Alfonso, and Mascolo (2002)

Cattell and Horn Gi-Gc Theory

Carroll's Three-Stratum Theory

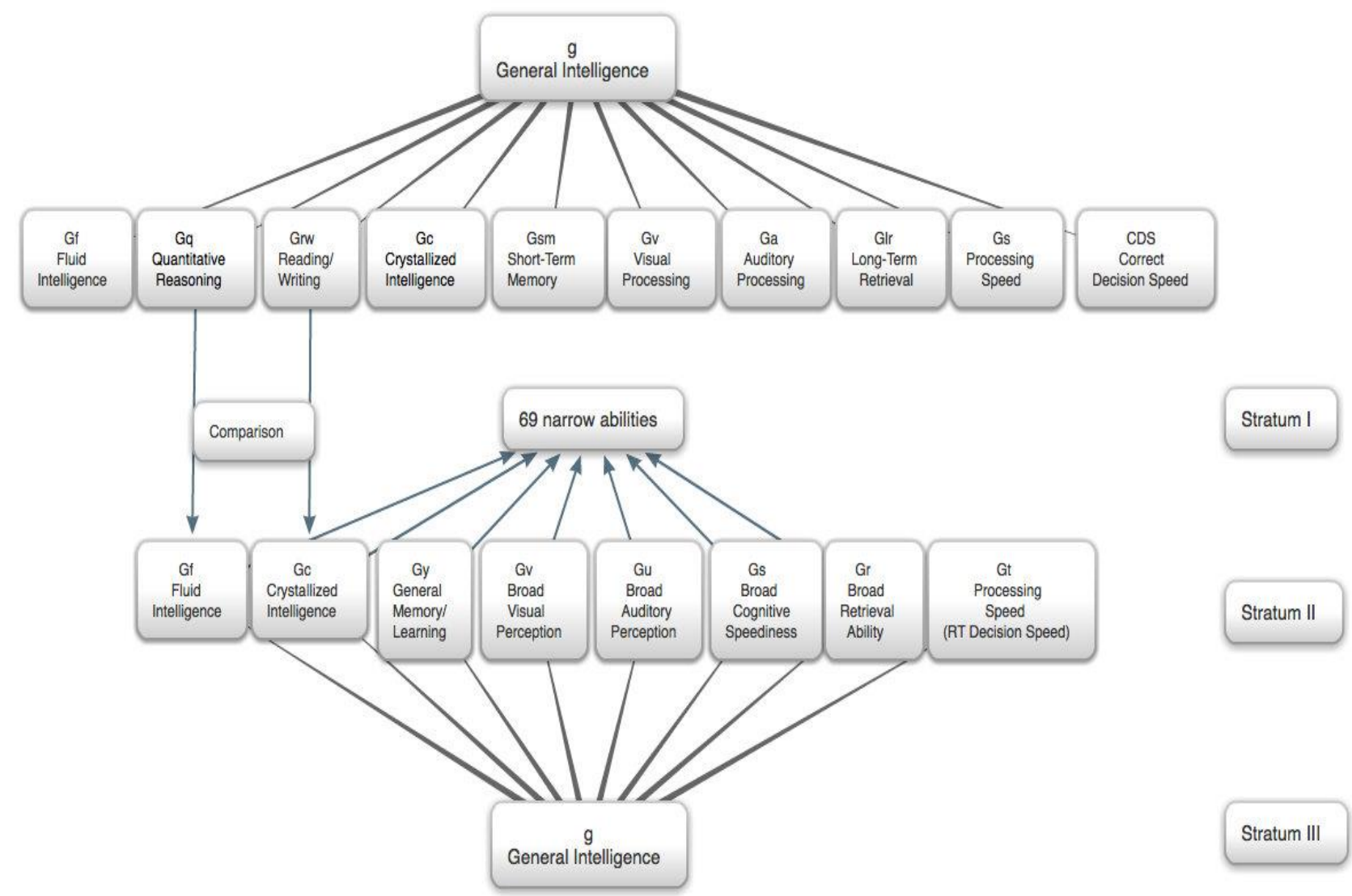

